Kongunadu Arts and Science College, Coimbatore.

\title{
EVALUATION OF ANTIOXIDANT COMPOUNDS AND FREE RADICAL SCAVENGING ABILITY OF POMEGRANATE FRUIT PEELS
}

\author{
Jamuna, $\mathbf{S}^{*}$., S. Sathiskumar and M. Swamynathan \\ Department of Botany, Kongunadu Arts and Science College, Coimbatore-641029. \\ *E.mail: sjamunaphd@gmail.com
}

\section{ABSTRACT}

The present study was undertaken to investigate the phytochemical profile and antioxidant activity of pomegranate fruit peels. Qualitative and quantitative phytochemical analyses were made for various solvent extracts of fruit peel of pomegranate and for antioxidant activity, ethanolic extract alone was used. The preliminary phytochemical analysis revealed that higher number of secondary metabolites was found in ethanolic extract of fruit peel than the other solvent extracts. The total phenolics and flavonoids contents of ethanolic fruit peel extract was found to be $246.5 \mathrm{mg} \mathrm{GAE} / 100 \mathrm{~g}$ extract and $83.95 \mathrm{mg} \mathrm{QE} / 100 \mathrm{~g}$ extract respectively. The ethanolic fruit peel extracts unveiled highest scavenging ability by quenching the DPPH free radicals with the $\mathrm{IC}_{50}$ value, $142.90 \mu \mathrm{g} / \mathrm{mL}$. The present study showed that the tested pomegranate peels exhibited strong antioxidant activity. These results suggest that pomegranate fruit peel could be exploited as a potential source of natural antioxidant agent.

Keywords: Pomegranate, fruit peel, phytochemical analysis, antioxidant activity.

\section{INTRODUCTION}

Fruits are an important component of a healthy diet. In the recent years, more attention has been paid to the antioxidants contained in fruits. Antioxidants in fruit have been reported to reduce oxidative damage in our body (Halliwell, 2012). The antioxidants are known to play an important role in ameliorating oxidation process by quenching free radicals, chelating metals and scavenging oxygen in foods and biological systems (Anwar and Przybylski, 2012). In general, fruit skin contains a higher concentration of antioxidant substances than the flesh of the fruit (Awad et al., 2001). High fruit intakes reduce the mortality and morbidity of cardiovascular disease and some types of cancer (Guo et al., 2003).

Pomegranate (Punica granatum L.) is belongs to the family, Punicaceae has gained popularity in recent years due to its multifunctionality and nutritional benefit in the human diet. It is rich in tannins and other biochemicals, predominantly phenolics, which have been reported to reduce disease risk (Martinez et al., 2006; Jaiswal et al., 2010). A paste of its green leaves is applied on eyes in conjunctivitis and their juice is given in dysentery. The bark of the roots and stem is considered astringent and anthelmintic and specially used against tape worm, the fruit juice is considered cooling and refrigerant (Anil kumar, 1999). Pomegranate fruit peel constitutes about $50 \%$ of the total fruit weight (Al-Said et al., 2009), and it is often discarded as waste. However, the fruit peel contains higher amounts of polyphenol compounds than the juice, and it possesses stronger biological activities (Li et al., 2006; Hajimahmoodi et al., 2008; Gozlekci et al., 2011). Therefore, the present study was aimed at to elucidate the phytochemical contents and antioxidant activity of various solvent extracts of Pomegranate fruit peels.

\section{MATERIALS AND METHODS}

\subsection{Collection of plant materials}

The ripen fruit peel samples of Punica granatum was collected at local market, Coimbatore. The peel of the fruits was shade dried and powdered.

\subsection{Extracts preparation}

Powdered plant samples were extracted using successive solvents viz., petroleum ether, chloroform and ethanol by cold extraction $(20 \mathrm{~g} / 200 \mathrm{ml})$. After extraction, the extracts were filtered and evaporated under room temperature. The yield of the fruit peel extracts was analysed by following formula

Percentage yield $=\frac{\text { Amount of residue taken }}{\text { Amount plant powder taken }} 100$

\subsection{Phytochemical analysis}

The ethanolic extract was subjected to preliminary phytochemical analysis as described by Harborne (1998) and Trease and Evan (2002). The 
total phenolics and flavonoids content were evaluated and expressed as gallic acid equivalents (GAE) mg/100g (10 to $\left.50 \mu \mathrm{g} / \mathrm{ml} ; \mathrm{R}^{2}=0.996\right)$

(Siddhuraju and Becker, 2003) and rutin (RE) $\mathrm{mg} / 100 \mathrm{~g}$ equivalents ( 10 to $200 \mu \mathrm{g} / \mathrm{ml} ; \mathrm{R}^{2}=0.991$ ) (Zhishen et al., 1999) respectively.

\subsection{DPPH radical scavenging activity}

The ability of pomegranate fruit peel extract to scavenge the 2,2-diphenyl-1-picrylhydrazyl $(\mathrm{DPPH} \bullet$ ) radicals was assessed by using Blois (1958) method with some modifications. $0.2 \mathrm{mM}$ solution of $\mathrm{DPPH}^{\bullet}$ in methanol was prepared and $500 \mu \mathrm{L}$ of this solution was added to different concentrations of the extracts $(50-300 \mu \mathrm{g} / \mathrm{mL})$. The mixture was shaken vigorously and allowed to stand for $30 \mathrm{~min}$ at room temperature. Control was prepared as above but without the sample extracts and methanol was used for the baseline correction. Then changes in the absorbance of the plant samples were measured at $517 \mathrm{~nm}$ using spectrophotometer. A lower absorbance value indicates the higher radical scavenging activity. Results were compared with the standard antioxidants (rutin, quercetin, BHA and BHT). The ability of DPPH radical scavenging activity was calculated by using the following formula:

$\mathrm{DPPH} \cdot$ scavenging effect $(\%$ of inhibition $)=\left[\left(\mathrm{A}_{0^{-}}\right.\right.$ $\left.\left.A_{1}\right) / A_{0}\right] X 100$

Where, $A_{0}$ is the absorbance of the control, and $A_{1}$ is the absorbance of the extracts. The $\mathrm{IC}_{50}$ (the microgram of extract to scavenge $50 \%$ of the radicals) value was calculated using linear regression analysis. Lower $\mathrm{IC}_{50}$ value indicates greater antioxidant activity.

\subsection{Statistical analysis}

Analysis was carried out in triplicates and mean \pm SD (Standard Deviation) using Duncan's

Multiple Range Test (DMRT) (Duncan, 1955). Statistical significance $(p<0.05)$ were subjected to one way analysis of variance (ANOVA) by using a statistical Package for Social Science (SPSS) (Version 9, SPSS, Inc., Chicago, USA).

\section{RESULTS}

\subsection{Percentage yield}

Percentage yield of various solvent extracts of pomegranate fruit peels are given in Table 1 . The chloroform and ethanol extracts showed higher percentage yield (9.52 and $4.76 \%)$ than the petroleum ether extract $(2.15 \%)$.
Table 1. Percentage yield of various solvent extracts of pomegranate fruit peels.

\begin{tabular}{llll}
\hline $\begin{array}{l}\text { Name of the } \\
\text { plant }\end{array}$ & $\begin{array}{c}\text { Petroleum } \\
\text { ether }\end{array}$ & Chloroform & Ethanol \\
\hline $\begin{array}{l}\text { Punica } \\
\text { granatum }\end{array}$ & 2.15 & 4.76 & 9.52 \\
\hline
\end{tabular}

\subsection{Phytochemical analysis}

\subsubsection{Preliminary phytochemical analysis}

Table 2 shows the preliminary phytochemical analysis of different solvent extracts of pomegranate fruit peels. Among the three extracts, the ethanol extract revealed the presence of the major phytochemicals viz., glycosides, flavonoids, phenols, saponins, steroids, tannins and terpenoids.

Table 2. Qualitative phytochemical analysis of various solvent extracts of pomegranate fruit peels.

\begin{tabular}{|c|c|c|c|c|}
\hline $\begin{array}{c}\text { S.N } \\
0 .\end{array}$ & Phytochemical test & $\begin{array}{l}\text { Petroteu } \\
\text { m ether }\end{array}$ & $\begin{array}{c}\text { Chlorofor } \\
\text { m } \\
\end{array}$ & $\begin{array}{c}\text { Ethan } \\
\text { ol }\end{array}$ \\
\hline $\begin{array}{l}1 . \\
2 .\end{array}$ & $\begin{array}{l}\text { Alkaloids } \\
\text { b) Meyer's Test } \\
\text { Cardiac Glycosides }\end{array}$ & +++ & ++ & - \\
\hline 3. & $\begin{array}{l}\text { a) Keller killiani Test } \\
\text { Flavonodis }\end{array}$ & - & ++ & ++ \\
\hline 3. & a) Shinoda Test & - & - & - \\
\hline 4 & $\begin{array}{l}\text { b) Lead Acetate Test } \\
\text { Glycosides }\end{array}$ & +++ & + & +++ \\
\hline 4. & a) Keller Kiliani Test & - & - & - \\
\hline & $\begin{array}{l}\text { b) Legal's Test } \\
\text { Phenols }\end{array}$ & + & - & - \\
\hline 5. & 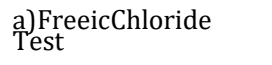 & + & - & ++ \\
\hline 6. & $\begin{array}{l}\text { Resins Test } \\
\text { Saponins }\end{array}$ & - & + & - \\
\hline 7. & $\begin{array}{l}\text { a)Frothing/Foam } \\
\text { Test } \\
\text { Steroids }\end{array}$ & ++ & + & ++ \\
\hline 8. & $\begin{array}{l}\text { a)Libermann- } \\
\text { Burchard's Test }\end{array}$ & - & ++ & ++ \\
\hline 9. & $\begin{array}{l}\text { Tannins } \\
\text { a) Braember's Test }\end{array}$ & - & - & +++ \\
\hline 10. & $\begin{array}{l}\text { Terpenoids } \\
\text { Salkowski Test }\end{array}$ & - & ++ & ++ \\
\hline 11. & $\begin{array}{l}\text { TriterpenoidsSalko } \\
\text { wski Test }\end{array}$ & - & - & - \\
\hline
\end{tabular}

\subsubsection{Quantitative phytochemical analysis}

The total phenolics and flavonoids contents of ethanolic extract of pomegranate fruit peels are given in Table 3 . The total phenolics content was found to be $246.51 \pm 0.17 \mathrm{mg}$ GAE $/ 100 \mathrm{~g}$ extract and the flavonoids content was $83.95 \pm 0.60 \mathrm{mg} \mathrm{RE} / 100 \mathrm{~g}$ extract. 
Table 3. Quantitative phytochemical analysis of ethanolic extracts of pomegranate fruit peels.

\begin{tabular}{|c|c|c|}
\hline $\begin{array}{c}\text { Name of the } \\
\text { Plant }\end{array}$ & $\begin{array}{l}\text { Total phenolics } \\
\text { (mg GAE/100 g } \\
\text { extract) }\end{array}$ & $\begin{array}{c}\text { flavonoids } \\
\text { (mg QE/100 g } \\
\text { extract) }\end{array}$ \\
\hline $\begin{array}{l}\text { Punica } \\
\text { granatum }\end{array}$ & $246.51 \pm 0.17^{\mathrm{a}}$ & $83.95 \pm 0.60^{\mathrm{a}}$ \\
\hline \multicolumn{3}{|c|}{$\begin{array}{l}\text { granatum } \\
\text { GAE - Gallic Acid Equivalent, QE - Quercetin Equivalent. } \\
\text { Values are performed in triplicates and represented as mean } \pm \mathrm{SD} \\
\text { (standard deviation). } \\
\text { Mean values followed by different superscripts in a column are } \\
\text { significantly different }(p<0.05) \text {. }\end{array}$} \\
\hline
\end{tabular}

\subsubsection{DPPH radical scavenging activity}

The data of DPPH radical scavenging activity of pomegranate fruit peel ethanolic extracts is exhibited in Table 4. The percentage inhibition of DPPH radicals was increased with the increasing concentration of extracts $(50,100,150,200,250$ and $300 \mu \mathrm{g} / \mathrm{ml}$ ). The $\mathrm{IC}_{50}$ value of the pomegranate fruit peel was determined to be $142.9 \mu \mathrm{g} / \mathrm{ml}$. The free radical scavenging activity of the sample was compared with that of the standard (natural and synthetic) antioxidants.

Table 4. DPPH radical scavenging activity of ethanolic extract of pomegranate fruit peels and standard antioxidants.

\begin{tabular}{lcll}
\hline $\begin{array}{l}\text { Sample } \\
\text { concent } \\
\text { ration } \\
(\boldsymbol{\mu g} / \mathbf{m l})\end{array}$ & $\begin{array}{c}\text { \% of } \\
\text { Inhibition }\end{array}$ & $\begin{array}{c}\text { Standard } \\
\text { antioxidant } \\
\mathbf{s}\end{array}$ & $\mathbf{I C}_{\mathbf{5 0}}(\boldsymbol{\mu g} / \mathbf{m l})$ \\
\hline 50 & $20.00 \pm 0.02^{\mathrm{d}}$ & Rutin & $42.07 \pm 0.00^{\mathrm{b}}$ \\
100 & $44.82 \pm 0.03^{\mathrm{c}}$ & Quercetin & $50.82 \pm 4.00^{\mathrm{c}}$ \\
150 & $51.02 \pm 0.04^{\mathrm{b}}$ & BHT & $52.97 \pm 8.23^{\mathrm{d}}$ \\
200 & $63.48 \pm 0.02^{\mathrm{ab}}$ & BHA & $38.47 \pm 1.03^{\mathrm{a}}$ \\
250 & $74.61 \pm 0.10^{\mathrm{a}}$ & & \\
300 & $84.92 \pm 0.12^{\mathrm{a}}$ & & \\
$\mathrm{IC}_{50}$ & $142.90 \pm 0.45^{\mathrm{b}}$ & & \\
\hline
\end{tabular}

Values are performed in triplicates and represented as mean \pm SD (standard deviation).

Mean values followed by different superscripts in a column are significantly different $(p<0.05)$.

BHT - ButylatedHydroxy toluene; BHA - ButylatedHydroxy Anisole

\section{DISCUSSION}

Interest in finding naturally occurring antioxidants for use in foods or medicinal materials to prevent free radical imbalance has increased considerably over the past few year (Mahdavi and Salunkhe, 1995). Use of synthetic antioxidants viz., butylated hydroxyl anisole (BHA) and butylated hydroxyl toluene (BHT) is restricted due to their carcinogenicity (Mahavi and Salunkhe, 1995). Therefore the need for identifying alternate, natural and safe source of antioxidants (especially of plant origin) has increased in recent years (Zainolet al. 2003). The therapeutic benefits of secondary metabolites of plant origin have been researched in several recent studies (Nayak and Lexiey, 2010). For this reason research has been focused on evaluating the antioxidant properties of medicinal plants.

Phytochemical analysis of pomegranate fruit peel extracts showed the presence of the antioxidant compounds viz., total phenolics and total flavonoids. Phenolic compounds have attracted much interest recently because in vitro and in vivo studies suggest that they have a variety of beneficial biological properties like anti-inflammatory, antitumor and antimicrobial activities (Mbaebae et al., 2012; Meenakshi et al., 2012). Phenolic studies have attributed that antioxidant properties are due to the presence of phenols and flavonoids (Turkoglue et al., 2007). Therefore, it is necessary to determine the total amount of phenols and flavonoids in the fruit peel extract taken for the study. Flavonoids are the most diverse and wide spread group of natural compounds are likely to be the most important natural phenolics. They act as a primary oxidant or free radical terminators. Antioxidant activity of phenolic compounds is based is their ability to donate hydrogen atom to free radicals.

The results of DPPH scavenging activity as in this study indicated that the pomegranate fruit peel was potentially active. The study suggested that pomegranate fruit peel extract contained compounds radical in order to remove odd electron which is responsible for radical's reactivity. The scavenging ability of DPPH radical by the fruit peel extracts was found to be appreciable which this implied that the fruit peel extracts might be useful for treating radical related pathological damages especially at higher concentrations (Wang et al., 1998).

\section{CONCLUSION}

In this study, a strong correlation between antioxidant activities and their total phenols and flavonoids was found in pomegranate fruit peel extracts. Thus, the pomegranate fruit peels could serve as potential source of natural antioxidants against oxidative stress, which is associated with neurodegenerative disease and biological damage in living tissues. It can be concluded that the species could serve as a natural source of antioxidants in the food industry and with its other pharmacological properties. Hence, further investigation is required to isolate and elucidate the active principles, and evaluate pharmacological properties using animal 
models before going for commercial production of drugs by pharmaceutical industries.

\section{REFERENCES}

Al-Said, F.A., L.U. Opara and R.A. Al-Yahyai, (2009). Physico-chemical and textural quality attributes of pomegranate cultivars (Punica granatum L.) grown in the Sultanate of Oman. J. Food Eng. 90:129-134.

Anil Kumar, D., (1999). Sacred plant and their medicinal uses. Daya Publishing House 237p.

Anwar F. and R. Przybylski, (2012). Effect of solvents extraction on the total phenolics and antioxidant activity of extracts from flaxseed (Linumus itatissimum L.). Acta Sci. Pol. Technol. Aliment. 11: 293-301.

Awad, M.A., A. de Jagar, L.H. van der Plas and A.R. van der Krol, (2001). Flavonoid and chlorogenic acid changes in peel of 'Elstar' and 'Jonagold' apples during developmentand ripening. Sci. Hortic. 90: 69-83.

Blois, M.S. (1958). Antioxidant determination by the use of a stable free radical. Nature 181: 11991200.

Duncan, D.B., (1955). Multiple range and multiple $F$ tests. Biometrics 11(1): 1-42.

Gözlekçi, Ș., O. Saraçoğlu, E. Onursal and M. Özgen, (2011). Total phenolic distribution of juice, peel, and seed extracts of four pomegranate cultivars. Pharmacognosy Mag. 7:161-164.

Guo, C., J. Yang, J. Wei, Y. Li, J. Xu and Y. Jiang, (2003). Antioxidant activities of peel, pulp and seed fractions of common fruits as determined by FRAP assay. Nutri. Res. 23: 1719-1726.

Hajimahmoodi, M., M.R. Oveisi, N. Sadeghi, B. Jannat, M. Hajibabi, E. Farahani, M.R. Akrami and R. Namdar, (2008). Antioxidant properties of peel and pulp hydroextract in ten Persian pomegranate cultivars. Pak. J. Biol. Sci. 11: 1600-1604.

Halliwell, B., (2012). Free radicals and antioxidants: Updating a personal view. Nutr. Revs. 70: 257265.

Harborne, J.B., (1998). Phytochemical methods: a guide to modern techniques of plant analysis. $3^{\text {rd }}$ ed. Chapman and Hall, London.

Jaiswal, V., A. DerMarderosian and J.R. Porter,
(2010). Anthocyanins and polyphenoloxidase from dried arils of pomegranate (Punica granatum L.). Food Chem. 118: 11-16.

Li, Y., C. Guo, J. Yang, J. Wei, J. Xu and S. Cheng, (2006). Evaluation of antioxidant properties of pomegranate peel extract in comparison withpomegranate pulp extract. Food Chem. 96: 254-260.

Li, B.B., B. Smith and M.M. Hossain, (2006). Extraction of phenolics from citrus peels. I. Solvent extraction method. Sep. Purif. Technol. 48: $182-188$.

Martınez, J.J., P. Melgarejo, F. Hernandez, D.M. Salazar and R. Martınez, (2006). Seed characterization of five new pomegranate varieties. Sci. Hort. 110: 241-246.

Mdacbae, B.O., H.O. Edeoga and AJ. Afolyan, (2012). Phytochemical analysis and antioxidants activities aqueous stem bark extract of Schotia lalifolia Jacq. Asian Pac. J. Trop. Biomed. 2(2): 118-124.

Meanakshi , S., S. Umayaparvathi, M. Arumugam and T. Balasubramaniam, (2012). In vitro antioxidant properties of FTIR analysis of two sea weeds of gulf of mannar. Asian Pac. J. Tropical Biomed.S66

Siddhuraju, P. and K. Becker, (2003). Antioxidant properties of various solvent extracts of total phenolic constituents from three different agroclimatic origins of drumstick tree (Moringaoleifera Lam.) leaves. J. Agric. Food Chem. 51(8): 2144-2155.

Trease, G. and S.M. Evans, (2002). Pharmacognosy. $15^{\text {th }}$ ed, Bailer Tindal, London.

Turkoglu, A., M.E. Duru and N. Merean, (2007). Antioxidant and antimicrobial activity of Russula delica Fr: an edible wild mushroom. Eurasian J. Analytical Chem. 2(1): 54-67.

Wang, M.J., M. Li, Y. Rangarajan, E.J. Shao Lavoie and T. Tuang, (1998). Antioxidative phenolic compounds from sage (Salvia officinalis). J. Agric. Food Chem. 46: 4869-4873.

Zhishen, J., T. Mengcheng and W. Jianming, (1999). The determination of flavonoid contents in mulberry and their scavenging effects on superoxide radicals. Food Chem. 64(4): 555559. 